\title{
FAKTOR LINGKUNGAN DAN PENGARUHNYA TERHADAP KEBERHASILAN INDUSTRI KECIL DI KOTA MALANG
}

\author{
Fitriyah \\ Fakultas Ekonomi Universitas Islam Negeri Maulana Malik Ibrahim Malang \\ J1. Gajayana No. 50, Telepon (0341) 558881, Fax. (0341) 558881, \\ E-mail: feuinmlg@yahoo.co.id
}

\begin{abstract}
Abtract
The aim of this study are to know what factors underlying the industrial success derived from extern and intern environment factors, whether or not the factors found have real influence and which of them that has the strongest influence to the success of the industrial achievement.

Population for this study are businessman and craftsman that specialize on 'kripik tempe' industry in Sanan district both from small scale and family scale industry. Sampling is taken by applying proportional random sampling for 47 respondents. The amount of research variables are 26 variables related to extern environment factors: buyer, supplier, technology, government, and intern factors: marketing, financial, and production. Success variables are measured in their profitability rate and business growth rate.

Result of the study showed that there are 7 factors underlying the success of the industry with determination coefficient of 0.590 , means that about $59 \%$ of the success of the industry can be explained by buyer, supplier, technology, government, marketing, financial, and production variables, while the remaining $(100 \%-59 \%)$ or $41 \%$ are explained by other causes unobserved in the research. There 4 factors including supplier, technology, marketing, and production variables partially have significant influence to the success of the industry, meanwhile buyer, government and financial partially don't have influence to the success of the industry. Production factor is the most dominant factor among the other factors.
\end{abstract}

Key words : environment analysis, performance industry, kripik tempe sanan

Abad 21 adalah abad perdagangan bebas dengan ditandai adanya pergerakan dunia menuju satu pasar dunia yang disebut globalisasi. Pada era ini batasan negara relatif longgar dan terjadi peningkatan lalu lintas barang dan jasa serta modal dan manusia, hal ini karena dipicu oleh adanya perubahan teknologi komunikasi dan informasi. Dalam era ini setiap negara maupun perusahaan berlomba-lomba untuk memanfaatkan peluang yang ada karena kemampuan 
suatu negara maupun perusahaan untuk bersaing di pasar global untuk menentukan keberhasilannya memasuki atau bertahan di era globalisasi tersebut. Kondisi persaingan yang semakin ketat tersebut mengharuskan perusahaan untuk mencari paradigma baru dan mengusahakan strategi bisnis yang jitu khususnya bidang pemasaran.

Dengan berubahnya tatanan ekonomi dunia tersebut menjadi era perdagangan bebas akan sangat berpengaruh terhadap kondisi perekonomian nasional. Perekonomian nasional salah satunya ditopang oleh tiga sendi perekonomian antara lain Badan Usaha Milik Negara (BUMN), perusahaan swasta dan Usaha Kecil Menengah (UKM) dan Koperasi, oleh karena itu adanya globalisasi maka ketiganya akan terkena dampak yang besar khususnya UKM dan Koperasi karena mereka banyak menghadapi permasalahan dan kelemahan intern serta keterbatasan-keterbatasan lainnya. UKM dan Koperasi merupakan komponen yang sangat penting serta mempunyai nilai yang strategis dalam pembangunan nasional, khususnya dalam penyerapan tenaga kerja, peningkatan pemerataan dan pendapatan masyarakat khususnya didaerah pedesaan. Data terakhir dari Menteri Negara Koperasi dan Pengusaha Kecil dan Menengah (Menekop \& PKM) menunjukkan bahwa pada tahun 2000, ada sekitar 38,99 juta Usaha Kecil dengan rata-rata penjualan per tahun kurang dari Rp 1 miliar, atau sekitar 99,85 \% dari jumlah perusahaan di Indonesia. Pada tahun yang sama, ada 55.061 perusahaan kategori Mengengah dengan rata-rata penghasilan pertahun lebih dari Rp 1 miliar tetapi kurang dari Rp 50 miliar, atau sekitar 0,14 \% dari jumlah unit usaha (Tulus Tambunan,2002).

Sumartono (2003) selaku Kadisperindag Kota Malang menyatakan bahwa baik Disperindag maupun asosiasinya selalu melakukan pembinaan secara rutin. Namun, pola pembinaan yang dilakukan Disperindag mengalami perubahan, bila dahulu menggunakan sistem top down sekarang dengan sistem bottom up yaitu memperhatikan keinginan industri kecil. Pemerintah lebih banyak menjadi fasilitator dan dinas lebih banyak menjadi penyedia informasi. Beberapa program yang telah disusun pemerintah untuk mengembangkan industri kecil adalah program penyelamatan meliputi program penumbuhan wirausaha baru, pengembangan pasar, pengembangan akses ke sumber bahan baku, peningkatan akses permodalan, peningkatan akses dan program peningkatan daya saing 
meliputi program pengembangan sarana informasi, manajemen mutu dan teknologi, pengembangan sumber daya manusia, pengembangan kelembagaan, dan program pendukung. Dari sekian program yang disusun oleh pemerintah cukup memadai dan jika diterapkan dengan baik maka akan sangat membantu kehidupan industri kecil, namun pada kenyataannya tidak sedikit industri kecil yang masih belum merasakan sentuhan dari pemerintah.(Techno,2002)

Industri kecil memang sangat rentan terhadap perkembangan jaman, untuk itu yang paling mendasar yang mungkin terlebih dahulu dirombak untuk menghadapi globalisasi adalah terletak pada sistem, baik itu sistem hubungan antara industri kecil dengan pasar produknya maupun dengan pemerintah. Dalam menghadapi globalisasi industri-industri kecil mulai mempersiapkan diri dengan meningkatkan kualitas produk-produknya meskipun ada sebagian industri kecil tidak memperhitungkan atau mempersiapkan diri untuk pasar bebas dengan asumsi mereka tidak akan terimbas artau terpengaruh oleh pasar bebas

Tri Soesanto (2002) menyatakan bahwa kelemahan dari industri kecil yang ada sekarang adalah keseragaman produk khususnya kualitas sehingga produksi yang sekarang bisa berbeda dengan produksi yang akan datang, kedua adalah masalah sanitasi kurang diperhatikan karena usaha mereka pada umumnya adalah home industri sehingga jarang memperhatikan sanitasi, ketiga adalah modal yaitu industri kecil biasanya memasarkan produknya dengan cara menitipkan produknya pada para pelanggan sehingga produksi sekarang tidak langsung memperoleh uang melainkan esok harinya atau bahkan setelah tiga kali produksi, sehingga biaya produksi bisa tiga kali lipat dan hal ini sangat menyulitkan industri kecil. Hal senada juga dikemukakan Sri Kumalaningsih (2002) bahwa industri kecil kurang dapat maju dan berkembang karena kelemahan terbesarnya adalah pada kualitas produk, sedangkan dari segi pemasaran industri-industri kecil sudah mempunyai market (pasar) sendiri dan kadang-kadang mempunyai saingan yang berat dari sesama industri kecil.

Industri kecil pada umumnya menggunakan manajemen tradisional dimana proses manajemen dilakukan secara sederhana dan dilakukan langsung oleh pimpinan yang sekaligus pemilik industri yang bersangkutan. Seperti industri roti, kripik tempe, tahu dan industri kerupuk semuanya menyatakan 
bahwa pengaturan industri sepenuhnya dilakukan oleh pemilih industri, meskipun dalam bidang-bidang tertentu seperti bidang produksi, pemasaran, keuangan dan administrasi sudah dikerjakan orang lain namun tetap dalam pengawasan langsung pemilik industri. Oleh karena itu banyak pengusaha kecil dan menengah yang menghadapi kesulitan / permasalahan dalam penetapan variabel-variabel strategis dalam pengambilan keputusan yang bersifat strategis. Para pengusaha tersebut dalam mengambil keputusan masih didasarkan pada intuisi, dugaan atau aturan-aturan yang belum teruji. Selain itu masalah mendasar lainnya dari industri kecil adalah kurangnya manajemen strategis secara keseluruhan, mulai dari ketidakmampuan strategi efektif untuk mencapai pelanggan sampai kegagalan untuk mengembangkan sistem pengukuran dan kontrol kinerja. Banyak pengusaha kecil dan menengah dalam praktek perencanaan strategis yang dilakukan oleh pemilik atau manajer perusahaan kecil dilakukan dengan minim dan tidak mendalam hanya sebagai rutinitas saja.Walaupun demikian mereka merasa tidak ada permasalahan dalam strategi bisnis. Fenomena ini bisa berjalan dalam jangka pendek selama globalisasi ekonomi belum diterapkan sepenuhnya. Bila pasar global telah diterapkan dan persaingan semakin tajam maka masalah manajemen bisnis akan dijumpai oleh pengusaha kecil menengah. Untuk itu permasalahan tersebut perlu diantisipasi sedini mungkin.

Pada era pasar bebas ini dimana tingkat persaingan yang tinggi, pelaku bisnis dituntut menitik beratkan pada faktor-faktor baik intern maupun ekstern yang mempengaruhi industri baik secara langsung maupun tidak langsung. Kinerja suatu perusahaan dapat dipengaruhi oleh dua efek yaitu efek strategi intern perusahaan dan efek lingkungan ekstern perusahaan. Suatu perusahaan supaya dapat mengembangkan usahanya dengan baik maka perusahaan tersebut harus dapat menyusun strategi yang tepat. Agar strategi yang disusun oleh perusahaan tepat maka perusahaan harus mempertimbangkan dan mempelajari faktor-faktor lingkungan yang mempengaruhi perusahaan tersebut baik faktor intern maupun ekstern. Dengan mempelajari lingkungan intern dan ekstern maka perusahaan akan dapat mengetahui peluang dan ancaman yang dihadapi perusahaan selain itu perusahaan akan dapat mengetahui apa kelebihan dan kelemahan perusahaan sehingga diharapkan strategi yang dikeluarkan oleh 
perusahaan akan dapat efektif dan tepat dan lebih lanjut akan dapat memenangkan persaingan yang ada di era global tersebut.

Pemerintah berupaya mengurangi ketimpangan pemerataan pembangunan salah satunya dengan program-program pembinaan maupun kegiatan pemberdayaan oleh lembaga swadaya masyarakat. Berbagai upaya telah banyak dilakukan oleh pemerintah untuk mengatasi ketimpangan tersebut antara lain dalam bentuk program-program pengembangan usaha kecil yang memiliki porsi strategis dalam rangka mengurangi ketimpangan. Walaupun usaha-usaha tersebut telah dilakukan tetapi dalam kenyataannya program tersebut tidak begitu berhasil perkembangan industri kecil masih jauh tertinggal dibandingkan dengan industri yang lain. Hal ini disebabkan terdapatnya beberapa kelemahan yang melekat pada industri kecil baik yang bersifat intern maupun yang bersifat ekstern.

Berbagai masalah dan kendala yang dihadapi industri kecil menyebabkan kurang berhasil atau gagalnya kegiatan usaha industri kecil tersebut. Masalah dan kendala yang menyebabkan kegagalan usahanya berasal dari faktor internal perusahaan tersebut maupun dari luar industri kecil itu. Beberapa faktor ekstern yang menyebabkan kegagalan industri kecil tersebut antara lain teknologi, pelanggan, pemasok, persaingan diantara industri, dan lain sebagainya. Sedangkan faktor intern yang menyebabkan kegagalan industri kecil adalah faktor pemasaran, kondisi keuangan, dan faktor manajemen tidak mampu mengelola usaha dengan baik / manajemen tidak efisien.

Sehubungan dengan hal tersebut di atas, peneliti tertarik untuk melakukan penelitian terhadap analisis lingkungan dari industri kecil baik lingkungan ekstern maupun intern. Penelitian dilakukan di daerah Sanan yang merupakan sentra industri tempe dan kripik tempe yang ada di Kota Malang.

berdasarkan latar belakang, maka perumusan masalah dalam penelitian ini adalah Apakah faktor-faktor lingkungan baik ekstern (pembeli, pemasok, teknologi, pemerintah) maupun intern (pemasaran, keuangan dan produksi) secara simultan maupun parsial berpengaruh signifikan terhadap keberhasilan industri kripik tempe di Sanan Kota Malang.

Tujuan yang ingin dicapai dalam penelitian ini adalah sebagai berikut: 
untuk menganalisis pengaruh secara simultan maupun parsial dari faktor-faktor lingkungan baik lingkungan ekstern (pembeli, pemasok, teknologi, pemerintah) maupun intern (pemasaran, keuangan dan produksi) terhadap keberhasilan industri kecil kripik tempe di daerah Sanan Kota Malang.

\section{METODE}

Jenis penelitian yang digunakan adalah explanatory research, yaitu penelitian yang menjelaskan hubungan kasual antara variabel-variabel melalui pengujian hipotesis (Masri Singarimbun,2000)

Lokasi penelitian ditetapkan di daerah Sanan Kota Malang. Dipilihnya daerah ini, karena di daerah Sanan merupakan salah satu daerah yang merupakan pusat industri Kripik Tempe di Jawa Timur, baik itu sektor industri berskala kecil maupun Rumah Tangga.

Sedangkan obyek penelitian adalah pengrajin / pengusaha industri berskala kecil (IK) dan rumah tangga (IRT) yang bergerak dalam bidang produksi kripik tempe, dimana produk kripik tempe merupakan produk unggulan yang sedang dikembangkan oleh pemerintah Kota Malang.

\section{Populasi dan Sampel Penelitian}

Populasi pada penelitian iniadalah sentra industri kripik tempe yang ada di Kota Malang terdapat di Kecamatan Blimbing khususnya didaerah Sanan baik berskala Industri Kecil (IK) maupun yang berskala Industri Rumah Tangga (IRT).

Tabel 1

Jumlah Populasi Pengrajin Kripik Tempe di daerah Sanan

\begin{tabular}{|c|c|c|}
\hline No & Kategori Industri & Populasi \\
\hline 1. & Industri & 77 \\
\hline 2. & $\begin{array}{l}\text { Tangga } \\
\text { Industri Kecil }\end{array}$ & 12 \\
\hline & Jumlah & 89 \\
\hline
\end{tabular}

Sumber : Data primer

Penentuan jumlah sampel dalam penelitian ini menggunakan pendekatan dari Slovin (Husein Umar, 1999) sebagai berikut:

$$
\mathrm{n}=\frac{N}{1+N e^{2}}=47
$$

Dimana : 
$\mathrm{n}$ = Ukuran sampel

$\mathrm{N}=$ Ukuran populasi

e $=\%$ kelonggaran ketidaktelitian karena kesalahan pengambilan sampel yang masih dapat ditolerir.

Dalam penelitian ini ditetapkan e sebesar $10 \%$, sedangkan besarnya $\mathrm{N}$ adalah 89, sehingga jumlah sampel minimal yang ditetapkan sebanyak 47 responden. Jumlah ini didasarkan pada pertimbangan alat analisis yang dipilih dengan mensyaratkan ketentuan sampel minimal sebesar 4 atau 5 kali jumlah variabel (Maholtra, 1999).

Cara pengambilan sampel yang digunakan adalah Probability Sampling/ Random sampling. Sedangkan prosedur pengambilannya yaitu Stratified Random Sampling. Prosedur tersebut dipilih karena populasinya bersifat heterogen, sehingga dengan mengelompokkan menjadi beberapa strata diharapkan tiap stratum menjadi relatif homogen.

Tabel 2

Jumlah Sampel pada masing-masing Kategori Industri.

\begin{tabular}{|l|c|l|c|}
\hline Kategori Industri & $\begin{array}{c}\text { Populasi } \\
\text { Pengrajin }\end{array}$ & $\begin{array}{c}\text { Pengambilan } \\
\text { Sampel }\end{array}$ & $\begin{array}{c}\text { Jumlah } \\
\text { Sampel }\end{array}$ \\
\hline $\begin{array}{l}\text { Industri Rumah } \\
\text { Tangga (IRT) }\end{array}$ & 77 & $\frac{77}{89} \times 47$ & 41 \\
Industri Kecil (IK) & 12 & $\frac{12}{89} \times 47$ & 6 \\
\hline \multicolumn{1}{|c|}{ Total } & 89 & & 47 \\
\hline
\end{tabular}

Penelitian ini menggunakan dua sumber data, yaitu data primer yang berasal dari responden langsung dan data sekunder yang diperoleh dari instansi yang terkait dengan penelitian (data primer) yang dijadikan sampel penelitian. misalnya laporan-laporan atau dokumen yang berasal dari Biro Pusat Statistik, Dinas Perindustrian dan Perdagangan dan instansi terkait lainnya.

\section{Teknik Pengumpulan Data}

Teknik pengumpulan data yang digunakan dalam penelitian ini menggunakan Kuesioner, dilakukan dengan mengajukan pertanyaan yang sifatnya kombinasi terbuka dan tertutup kepada responden.

Identifikasi Variabel. 
Dalam penelitian ini terdapat variabel independen yang terdiri dari Pembeli(X1), Pemasok (X2), Teknologi (X3), Pemerintah (X4), Pemasaran (X5) Keuangan (X6) Produksi (X7). Sedangkan variabel dependennya adalah Keberhasilan Industri (Y).

Tabel 3

Penjabaran Variabel Penelitian

\begin{tabular}{|c|c|c|}
\hline No & Variabel & indikator \\
\hline \multicolumn{3}{|c|}{ Variabel bebas yang berkaitan dengan Lingkungan Ekstern } \\
\hline \multirow[t]{3}{*}{1} & \multirow[t]{3}{*}{ Pembeli $\left(\mathrm{X}_{1}\right)$} & $\begin{array}{l}\mathrm{X}_{11}: \text { Kemudahan pembeli mendapatkan } \\
\text { produk }\end{array}$ \\
\hline & & $\mathrm{X}_{12}:$ Kualitas produk yang diharapkan pembeli \\
\hline & & $\begin{array}{l}\mathrm{X}_{13}: \text { Keragaman produk yang diinginkan } \\
\text { pembeli }\end{array}$ \\
\hline \multirow{3}{*}{2} & \multirow{3}{*}{ Pemasok $\left(\mathrm{X}_{2}\right)$} & $\mathrm{X}_{21}$ : Jumlah pemasok bahan baku \\
\hline & & $\begin{array}{l}\mathrm{X}_{22}: \text { Ketersediaan dan kemudahan } \\
\text { memperoleh } \mathrm{BB}\end{array}$ \\
\hline & & $\mathrm{X}_{23}$ : Harga bahan baku \\
\hline \multirow[t]{2}{*}{3} & \multirow[t]{2}{*}{ Teknologi $\left(\mathrm{X}_{3}\right)$} & $\begin{array}{l}\mathrm{X}_{31}: \text { Ketepatan penggunaan tekn yg } \\
\text { digunakan dlm proses prod }\end{array}$ \\
\hline & & $\mathrm{X}_{32}$ : Efektifitas penggunaan teknologi \\
\hline \multirow{3}{*}{4} & \multirow{3}{*}{$\begin{array}{l}\text { Pemerintah } \\
\left(\mathrm{X}_{4}\right)\end{array}$} & : Sarana dan prasarana \\
\hline & & Dukungan perijinan \\
\hline & & Dukungan pemasaran \\
\hline
\end{tabular}

\begin{tabular}{|c|c|c|}
\hline \multirow{5}{*}{5} & \multirow{5}{*}{$\begin{array}{l}\text { Pemasaran } \\
\left(\mathrm{X}_{5}\right)\end{array}$} & $\mathrm{X}_{51}$ : Reputasi pelayanan \\
\hline & & $X_{52}:$ Mutu / kualitas produk perusahaan \\
\hline & & $\begin{array}{l}\mathrm{X}_{53} \text { : Efektifitas promosi yang dilakukan } \\
\text { perusahaan }\end{array}$ \\
\hline & & $X_{54}$ : Efektifitas penentuan harga \\
\hline & & $X_{55}$ : Efektifitas inovasi \\
\hline \multirow{3}{*}{6} & \multirow{3}{*}{$\begin{array}{l}\text { Keuangan } \\
\left(X_{6}\right)\end{array}$} & $\mathrm{X}_{61}$ : Biaya dan adanya modal \\
\hline & & $\mathrm{X}_{62} \quad$ : Arus uang tunai \\
\hline & & $\mathrm{X}_{63}$ : Stabilitas keuangan \\
\hline \multirow{5}{*}{7} & \multirow{5}{*}{ Produksi $\left(X_{7}\right)$} & $\mathrm{X}_{71}$ : Skala ekonomis produksi \\
\hline & & $\begin{array}{ll}X_{72} & \text { : Karyawan yang terampil }\end{array}$ \\
\hline & & $\mathrm{X}_{73}$ : Kapasitas / kemampuan produksi \\
\hline & & $\mathrm{X}_{74}$ : Ketepatan waktu dalam berproduksi \\
\hline & & $\mathrm{X}_{75}$ : Kemampuan teknis pengusaha \\
\hline \multicolumn{3}{|c|}{ Variabel terikat } \\
\hline \multirow[t]{2}{*}{8} & \multirow{2}{*}{$\begin{array}{l}\text { Keberhasilan } \\
\text { Industri }(\mathrm{Y})\end{array}$} & $\mathrm{Y}_{11}$ : Tingkat profitabilitas \\
\hline & & $Y_{12}$ : Tingkat pertumbuhan usaha \\
\hline
\end{tabular}




\section{Teknik Pengukuran Variabel}

Pengukuran data dengan skala Likert yang terdiri dari lima pilihan jawaban atas pertanyaan yang diajukan dan jawaban responden tiap item pertanyaan diberi skor 1 sampai dengan 5 dengan kriteria sesuai dengan item pertanyaan.

\section{Uji Validitas Instrumen}

Untuk menguji tingkat validitas data, dalam penelitian ini digunakan uji validitas konstruk (construct validity) dengan teknik korelasi "product moment" Syarat minimum untuk dianggap valid adalah nilai $\mathrm{r} \geq 0,361$ (Sugiyono,1999)

\section{Uji Reliabilitas Instrumen}

Dalam penelitian ini uji realibilitas data menggunakan pendekatan "Alpha Cronbach". Instumen dapat dikatakan handal (reliabel) bila memiliki koefisien keandalan sebesar 0,6 a tau lebih (Arikunto,1992).

Dalam penelitian ini analisis data yang digunakan adalah analisis faktor dan analisis regresi linier berganda.

\section{HASIL DAN PEMBAHASAN}

\section{Karakteristik Responden}

Perajin yang dijadikan sampel dalam penelitian ini adalah perajin kripik tempe yang ada di wilayah Sanan, kelurahan Purwantoro, kecamatan Blimbing. Sampel yang diambil adalah sebanyak 47 responden pengrajin kripik tempe. Karakteristik responden yang diamati dalam penelitian ini adalah :

\section{Umur Perajin Kripik Tempe}

Pengrajin kripik tempe di daerah penelitian tidak seluruhnya didominasi oleh pria, cukup banyak pengrajin kripik tempe yang berjenis kelamin wanita yaitu sebesar 13 orang. Pada umumnya umur pengrajin berkisar antara 20 sampai 60 tahun.

\section{Tingkat Pendidikan}

Berdasarkan data yang terkumpul bahwa tingkat pendidikan yang dimiliki para pengrajin kripik tempe di wilayah penelitian sebagian besar tergolong berpendidikan menengah ke bawah. Hal ini disebabkan kara pengrajin yang didominasi kaum muda enggan meneruskan pendidikannya ke jenjang 
yang lebih tinggi. Rata-rata selepas menamatkan SMU (Sekolah Menengah Umum) mereka cenderung tidak meneruskan sekolahnya dan langsung terjun sebagai pengrajin, baik membantu orang tuanya maupun berusaha sebagai pengrajin mandiri.

\section{Asal Ketrampilan}

Bila dilihat dari tingkat pendidikan diatas bahwa sebagian besar pengrajin kripik tempe di wilayah penelitian berpendidikan sekolah menengah ke atas, namun hal ini tidak nampak pengaruhnya terhadap keberhasilan usaha mereka bila tidak ditunjang oleh ketrampilan yang mereka miliki. Ketrampilan membuat kripik tempe dapat berasal dari bakat turunan orang tua, pengalaman kerja dan pelatihan / kursus yang pernah mereka ikuti.

\section{Jumlah Tenaga Kerja yang Digunakan}

Bila dilihat dari tenaga kerja yang dipakai oleh responden umumnya masih mempekerjakan antara 1-5 orang, yang berarti bahwa sebagian besar responden masih tergolong industri rumah tangga yang sifatnya informal.

\section{Analisis faktor}

Analisis faktor digunakan untuk menyederhanakan dan menentukan beberapa variabel dari 26 variabel yang diyakini sebagai sumber yang melandasi seperangkat variabel nyata. Hasil pengolahan data diinterprestasikan berdasarkan langkah-langkah analisis faktor sebagai berikut :

\section{Variabel-variabel yang tidakmemenuhi MSA}

Measures of Sampling Adequacy (MSA) adalah suatu pedoman untuk mengukur apakah suatu variabel itu memenuhi syarat kecukupan atau tidak untuk syarat analisis faktor. Batas kecukupan MSA adalah > 0,5 (Maholtra, 1999). Dari hasil analisis faktor menunjukkan ada 1 variabel yang tidak memenuhi syarat MSA dari 26 variabel yaitu mempunyai nilai MSA yang kurang dari 0,50 maka selanjutnya variabel tersebut dikeluarkan dari model. Variabel yang tidak memenuhi syarat tersebut selengkapnya dapat dilihat pada tabel 4 di bawah ini.

Tabel 4 Variabel yang Tidak Memenuhi Syarat MSA

\begin{tabular}{|c|c|c|}
\hline Variabel & Nama Variabel & MSA \\
\hline X5.1 & Reputasi pelayanan & 0,346 \\
\hline
\end{tabular}


Setelah variabel tersebut dikeluarkan, maka tinggal 25 variabel yang akan diproses untuk analisis faktor.

\section{Penentuan jumlah faktor}

Dalam penelitian ini metode yang digunakan adalah Principle Component Analysis (CPA) yang dikenal memberikan prosentase komulatif yang lebih baik dibandingkan dengan teknik lain. Penentuan jumlah faktor didasarkan pada nilai eigen value $>1,0$. sehingga apabila terdapat faktor yang memiliki Eigen value diatas 1,00 maka faktor tersebut digunakan dalam model. Sedangkan faktor dengan nilai Eigenvalue kurang dari 1,00 akan dikeluarkan dari model. (Maholtra, 1999).

Dari hasil analisis (lampiran 7) jumlah faktor yang didasarkan pada kriteria tersebut di atas adalah 8 faktor. Dalam penelitian ini diambil sekelompok variabel yang mempunyai nilai eigen value terbesar untuk mewakili suatu faktor. Hasil analisis dapat dilihat pada 5 berikut:

Tabel. 5

Faktor Inti

\begin{tabular}{|l|c|c|c|c|}
\hline No & Faktor & $\begin{array}{c}\text { Eigen } \\
\text { Value }\end{array}$ & $\begin{array}{c}\text { Percentage of } \\
\text { Variance }\end{array}$ & $\begin{array}{c}\text { Commulative Procentage of } \\
\text { Variance }\end{array}$ \\
\hline 1 & $\mathrm{X} 1$ & 1,115 & 47,146 & 47,146 \\
\hline 2 & $\mathrm{X} 2$ & 2,440 & 56,386 & 56,386 \\
\hline 3 & $\mathrm{X} 3$ & 1,919 & 55,754 & 55,754 \\
\hline 4 & $\mathrm{X} 4$ & 1,692 & 63,972 & 63,972 \\
\hline 5 & $\mathrm{X} 5$ & 2,711 & 79,965 & 79,965 \\
\hline 6 & $\mathrm{X} 6$ & 1,414 & 81,329 & 81,329 \\
\hline 7 & $\mathrm{X} 7$ & 3,191 & 54,225 & 54,225 \\
\hline 8 & $\mathrm{Y}$ & 1,946 & 97,285 & 97,285 \\
\hline
\end{tabular}

Kedelapan faktor tersebut dapat dikatakan sebagai faktor-faktor yang menentukan keberhasilan industri kripik tempe di daerah Sanan- Kota Malang.

\section{Rotasi Faktor}

Faktor matriks sebelum dilakukan rotasi menunjukkan hasil yang tidak sederhana strukturnya sehingga masih sulit untuk diinterprestasikan. Oleh karena itu diupayakan dengan melakukan rotasi faktor untuk memperoleh 
struktur yang sederhana sehingga mudah untuk menjelaskan seluruh faktor yang dianalisis dalam model.

Dengan menggunakan rotasi varimax diperoleh hasil bahwa setiap variabel yang memiliki factor loading tertinggi dikelompokkan kedalam faktor yang bersangkutan (common factor) sehingga tidak terjadi tumpang tindih antar variabel dalam kelompok faktor yang berbeda. Hasil rotasi dari matriks faktor dapat dilihat pada tabel 6 di bawah ini.

Tabel 6

Hasil Rotasi Varimax

\begin{tabular}{|c|c|c|c|c|}
\hline No & $\begin{array}{l}\text { Fakt } \\
\text { or }\end{array}$ & Variabel & $\begin{array}{c}\text { Faktor } \\
\text { Loading }\end{array}$ & $\begin{array}{c}\text { Nama } \\
\text { Faktor Baru }\end{array}$ \\
\hline 1 & $\mathrm{X} 1$ & $\begin{array}{l}\text { X1.1 : Kemudahan pembeli mendapatkan } \\
\text { produk } \\
\text { X1.2 : Kualitas produk yang diharapkan } \\
\text { pembeli } \\
\text { X1.3 : Keragaman produk yang diinginkan } \\
\text { pembeli }\end{array}$ & $\begin{array}{l}0,919 \\
0,524 \\
0,884\end{array}$ & Pembeli \\
\hline 2 & $\mathrm{X} 2$ & $\begin{array}{l}\text { X2.1 : Jumlah pemasok bahan baku } \\
\text { X2.2: Ketersediaan dan kemudahan } \\
\text { memperoleh BB } \\
\text { X2.3 : Harga bahan baku }\end{array}$ & $\begin{array}{l}0,764 \\
0,812 \\
0,671\end{array}$ & Pemasok \\
\hline 3 & $\mathrm{X} 3$ & $\begin{array}{l}\text { X3.1 : ketepatan teknologi yg digunakan } \\
\text { dlm proses produksi } \\
\text { X3.3 : efektifitas penggunaan teknologi. }\end{array}$ & $\begin{array}{l}0,747 \\
0,747\end{array}$ & Teknologi \\
\hline 4 & $\bar{X} 4$ & $\begin{array}{l}\text { X4.1 : Sarana dan prasarana } \\
\text { X4.2 : kemudahan perijinan } \\
\text { X4.3 : kemudahan pemasaran }\end{array}$ & $\begin{array}{l}0,753 \\
0,625 \\
0,676\end{array}$ & Pemerintah \\
\hline 5 & $\mathrm{X} 5$ & $\begin{array}{l}\text { X5.2: Mutu / kualitas produk perusahaan } \\
\text { X5.3 : efektifitas promosi yang dilakukan } \\
\text { perusahaan } \\
\text { X5.4 : efektifitas penentuan harga } \\
\text { X5.5: efektifitas inovasi }\end{array}$ & $\begin{array}{l}0,885 \\
0,850 \\
0,881 \\
0,954\end{array}$ & Pemasaran \\
\hline 6 & $\mathrm{X} 6$ & $\begin{array}{l}\text { X6.1 : biaya dan adanya modal } \\
\text { X6.2 : arus uang tunai } \\
\text { X6.3 : Stabilitas keuangan }\end{array}$ & $\begin{array}{l}0,915 \\
0,915 \\
0,875\end{array}$ & Keuangan \\
\hline 7 & $\mathrm{X} 7$ & $\begin{array}{l}\text { X7.1: skala ekonomis produksi } \\
\text { X7.2 : karyawan yang terampil } \\
\text { X7.3: kapasitas / kemampuan produksi } \\
\text { X7.4 : ketepatan waktu dalam berproduksi } \\
\text { X7.5 kemampuan teknis pengusaha }\end{array}$ & $\begin{array}{l}0,875 \\
0,870 \\
0,759 \\
0,597 \\
0,506\end{array}$ & Produksi \\
\hline 8 & $\bar{Y}$ & $\begin{array}{l}\text { Y1.1: Tingkat profitabilitas } \\
\text { Y1.2 : Tingkat pertumbuhan usaha }\end{array}$ & $\begin{array}{l}0,986 \\
0,986\end{array}$ & $\begin{array}{c}\text { Keberhasila } \\
\text { n }\end{array}$ \\
\hline
\end{tabular}

Sumber : Data diolah 


\section{Skor Faktor}

Karena tujuan analisis faktor adalah untuk mereduksi data guna analisis multivariate selanjutnya yakni analisis regresi berganda, maka proses analisis perlu dilanjutkan hingga penentuan skor faktor.

\section{Uji Ketepatan Teknik Analisis}

Berdasarkan hasil perhitungan diketahui bahwa teknik analisis yang digunakan dalam analisis faktor ini adalah tepat karena semua nilai variabel Component Matrix $>0,50$

\section{Analisis Regresi Berganda}

Hasil analisis variabel bebas lingkungan ekstern (pembeli, pemasok, teknologi, pemerintah) dan lingkungan intern (pemasaran, keuangan, produksi) yang mempengaruhi keberhasilan industri kripik tempe di Sanan Kota Malang adalah sebagai berikut:

Tabel 7

Hasil Analisis Regresi antara Variabel Bebas Lingkungan Ekstern dan Intern terhadap Variabel Terikat Keberhasilan Industri

\begin{tabular}{|c|c|c|c|c|}
\hline Variabel & $\mathrm{B}$ & $\mathrm{t}$ & Sig. $\mathrm{t}$ & Beta \\
\hline Constant & $-2,011 \mathrm{E}-$ & 0,000 & 1,000 & - \\
Pembeli $\left(X_{1}\right)$ & 16 & 1,266 & 0,211 & 0,172 \\
Pemasok $\left(X_{2}\right)$ & 0,172 & 2,452 & 0,018 & 0,262 \\
Teknologi $\left(X_{3}\right)$ & 0,262 & 1,829 & 0,046 & 0,247 \\
Pemerintah & 0,247 & 1,742 & 0,088 & 0,214 \\
$\left(X_{4}\right)$ & 0,241 & 2,798 & 0,007 & 0,324 \\
Pemasaran $\left(X_{5}\right)$ & 0,324 & 1,722 & 0,091 & 0,183 \\
Keuangan $\left(X_{6}\right)$ & 0,183 & 3,600 & 0,001 & 0,574 \\
Produksi $\left(X_{7}\right)$ & 0,574 & & \\
\hline \multicolumn{4}{|c|}{$: 0,802$} \\
R Square & $: 0,642$ \\
Adjusted R Square $: 0,590$ \\
F hitung & $: 12,320$ \\
Sif. F & $: 0,000$ \\
\hline
\end{tabular}

Sumber : Data diolah

Berdasarkan tabel 7 diatas, maka diperoleh persamaan regresi sebagai berikut:

$$
\begin{aligned}
\mathrm{Y}= & -2,011+0,172 \mathrm{X} 1+0,262 \times 2+0,247 \mathrm{X} 3+0,214 \mathrm{X} 4+0,324 \mathrm{X} 5+0,183 \text { X6 } \\
& +0,574 \mathrm{X} 7
\end{aligned}
$$

Keterangan:

Y : Keberhasilan industri

X1 : Pembeli 


$$
\begin{array}{ll}
\text { X2 } & \text { : Pemasok } \\
\text { X3 } & \text { : Teknologi } \\
\text { X4 } & \text { : Pemerintah } \\
\text { X5 } & \text { : Pemasaran } \\
\text { X6 } & \text { : Keuangan } \\
\text { X7 } & \text { : Produksi }
\end{array}
$$

Pengaruh Faktor Lingkungan Ekstern dan Intern Terhadap Variabel Terikat Secara Simultan

Model regresi dengan lebih dua variabel bebas digunakan Adjusted R2 sebagai koefisien determinasi (Singgih Santoso, 2001). Dari analisis regresi sebagaimana tercantum pada tabel diatas diperoleh hasil bahwa nilai koefisien determinasi Adjusted $\mathrm{R}^{2}=$ 0,590 Yang berarti bahwa 59,0 \% keberhasilan industri kripik tempe di Sanan dijelaskan oleh variabel pembeli, pemasok, teknologi, pemerintah, pemasaran, keuangan dan produksi. Sedangkan sisanya $(100 \%-59,0$ $\%=41,0 \%)$ disebabkan oleh sebab-sebab lain.

Nilai $\mathrm{F}_{\text {hitung }}=12,320$ dengan taraf signifikansi $\mathrm{a}<0,00$. oleh karena probabilitas $(0,00)$ lebih kecil dari 0,05 maka model regresi dapat dipakai untuk memprediksi variabel keberhasilan industri. Atau dapat dikatakan,variabel pembeli, pemasok, teknologi, pemerintah, pemasaran, keuangan dan produksi secara bersama-sama (simultan) mempunyai pengaruh yang signifikan terhadap keberhasilan industri.

\section{Pengaruh Faktor Lingkungan Ekstern dan Intern Terhadap Variabel Terikat Secara Parsial}

Berdasarkan uji $\mathrm{t}$ diketahui bahwa secara parsial variabel pemasok, teknologi, pemasaran dan produksi berpengaruh signifikan terhadap keberhasilan industri kripik tempe yang ada di daerah Sanan Kota Malang karena nilai signifikansi t lebih kecil dari $5 \%$. Sedangkan variabel pembeli, pemerintah, dan keuangan secara parsial tidak berpengaruh signifikan terhadap keberhasilan industri kripik tempe di daerah Sanan Kota Malang karena nilai signifikansi t lebih besar dari $5 \%$.

Tingkat keberhasilan industri kripik tempe di Sanan dipengaruhi oleh 4 variabel yaitu pemasok, teknologi, pemasaran dan produksi. Masing-masing variabel ini akan diuraikan pengaruhnya terhadap tingkat keberhasilan industri kripik tempe di Sanan sebagai berikut: 


\section{a. Pemasok}

Dari analisis regresi diperoleh bahwa variabel pemasok berpengaruh positif terhadap tingkat keberhasilan industri dengan koefisien regresi sebesar 0,172. Hal ini berarti bahwa apabila faktor-faktor lain sebagai variabel independen lainnya tetap, maka meningkatnya pengaruh faktor pemasok bagi pengrajin kripik tempe akan menguntungkan usahanya karena dapat mempengaruhi tingkat keberhasilan perusahaan yaitu peningkatan sebesar 0,172. Nilai koefisien regresi tersebut juga mempunyai arti bahwa variabel-variabel yang terdapat dalam faktor tersebut berpengaruh positif dan menunjukkan hubungan yang searah terhadap keberhasilan perusahaan industri kecil.

b. Teknologi

Dari analisis regresi diperoleh bahwa variabel teknologi berpengaruh positif terhadap tingkat keberhasilan industri dengan koefisien regresi sebesar 0,247. Hal ini berarti bahwa apabila faktor-faktor lain sebagai variabel independen lainnya tetap, maka meningkatnya pengaruh faktor teknologi akan menguntungkan usahanya karena dapat mempengaruhi tingkat keberhasilan perusahaan yaitu peningkatan sebesar 0,247. nilai koefisien regresi tersebut juga mempunyai arti bahwa variabel-variabel yang terdapat dalam faktor tersebut berpengaruh positif dan menunjukkan hubungan yang searah terhadap keberhasilan perusahaan industri kecil.

c. Pemasaran

Dari analisis regresi diperoleh bahwa variabel pemasaran berpengaruh positif terhadap tingkat keberhasilan industri dengan koefisien regresi sebesar 0,324. Hal ini berarti bahwa apabila faktor-faktor lain sebagai variabel independen lainnya tetap, maka meningkatnya pengaruh faktor pemasaran yang dimiliki oleh pengusaha / pengrajin kripik tempe akan menguntungkan usahanya karena dapat mempengaruhi tingkat keberhasilan perusahaan yaitu peningkatan sebesar 0,324. nilai koefisien regresi tersebut juga mempunyai arti bahwa variabel-variabel yang terdapat dalam faktor tersebut berpengaruh positif dan menunjukkan hubungan yang searah terhadap keberhasilan perusahaan industri kecil. 


\section{d. Produksi}

Dari analisis regresi diperoleh bahwa variabel produksi berpengaruh positif terhadap keberhasilan industri kripik tempe di daerah Sanan Kota Malang dengan nilai koefisien regresi sebesar 0,574. hal ini berarti bahwa apabila faktor-faktor sebagai variabel independen lainnya tetap, maka meningkatnya pengaruh faktor produksi akan menyebabkan pada peningkatan tingkat keberhasilan perusahaan industri kripik tempe sebesar 0,574 .

Implikasi Hasil Penelitian

Paparan hasil penelitian yang telah dilakukan diatas digunakan untuk menjawab hipotesis yang diajukan. Disamping itu, hasil penelitian ini diharapkan dapat memberikan informasi, baik bagi pengusaha / pengrajin maupun bagi peneliti-peneliti lain terhadap penggalian faktor-faktor yang melandasi dan mempengaruhi tercapainya keberhasilan suatu industri kecil ditinjau dari lingkungan ekstern maupun internnya maupun ditinjau dari sisi yang lain.

Secara simultan variabel pembeli, pemasok, teknologi, pemerintah, pemasaran, keuangan dan produksi mempunyai pengaruh yang signifikan terhadap keberhasilan industri kripik tempe di daerah Sanan Kota Malang, hal tersebut dapat dilihat dari nilai adjusted $\mathrm{R}$ Square sebesar 0,590 artinya bahwa keberhasilan industri kripik tempe di daerah Sanan Kota Malang dipengaruhi oleh variabel pembeli, pemasok, teknologi, pemerintah, pemasaran, keuangan dan produksi sebesar 59,0 \% secara bersama-sama. Sedangkan 41,0 \% dipengaruhi oleh faktor lain yang tidak dibahas dalam penelitian ini.

Secara parsial variabel pemasok, teknologi, pemasaran dan produksi berpengaruh signifikan terhadap keberhasilan industri kripik tempe di daerah Sanan Kota Malang. Sedangkan variabel pembeli, pemerintah dan keuangan tidak berpengaruh signifikan.

Variabel pemasok yang signifikan menunjukkan bahwa variabel tersebut sangat berpengaruh terhadap keberhasilan industri. Bagi pengusaha industri pemasok itu tidak hanya terbatas pengusaha pemasok. Artinya industri kripik tempe tidak terbatas beberapa pemasok. Pengusaha tersebut dapat mengambil 
bahan baku dari beberapa pemasok sekaligus, hal tersebut dikarenakan untuk mengantisipasi jika pemasok terjadi gejolak maka pengusaha tidak akan mati karena kurangnya pasokan. disini solusinya adalah pemerintah harus memberikan dukung dan kemudahan bagi industri kecil dalam memperoleh bahan baku yang akan digunakan dalam proses produksi. Selain itu industri kecil harus mampu menjalin kemitraan dengan pemasok dan pemerintah sehingga diharapkan terjadi sinergi antara ketiganya sehingga pada akhirnya akan terjadi saling menguntungkan diantara ketiganya.

Variabel teknologi yang signifikan menunjukkan bahwa variabel tersebut sangat mempengaruhi tingkat keberhasilan industri. Teknologi yang digunakan hendaknya mulai dirubah dari teknologi yang teradisional ke semi modern dan pada akhirnya menggunakan teknologi modern karena hal tersebut sangat mempengaruhi kualitas dari kripik tempe yang dihasilkan. Dalam menggunakan teknologi perlu dilakukan suatu temuan baru dalam memproduksi kripik tempe yaitu mulai dari proses produksi kripik tempe itu sendiri, pola penggorengan kripik tempe dengan teknologi tepat guna dan proses pengemasan dan pengepakan.

Variabel pemasaran mempunyai nilai yang signifikan hal tersebut menunjukkan bahwa variabel tersebut sangat berpengaruh terhadap keberhasilan industri. Kripik tempe sebagai primadona kota malang dapat berfungsi sebagai oleh-oleh, sebagai camilan / produk makanan ringan dan produk hidangan, maka hendaknya kegiatan pemasaran tidak hanya terbatas di Kota Malang tetapi bisa ke luar daerah. Agar dapat terealisasi maka pengusaha dituntut mempertimbangkan pemilihan bahan baku yang baik, proses produksi dengan menggunakan teknologi tepat guna dan proses pembungkusan dan pengemasan yang baik sehingga diharapkan masa kadarluasa dan tingkat renyanyannya tetap terjaga.

Variabel produksi mempunyai nilai yang signifikan hal tersebut menunjukkan bahwa produksi sangat berpengaruh terhadap keberhasilan industri. Proses tersebut dimulai dari pemilihan bahan baku yang akan digunakan, dengan pemilihan bahan baku tempe yang baik dan dilanjutkan dengan proses pembuatan tempe yang baik, proses pemotongan tempe yang baik kemudian proses penggorengan yang baik dan dilanjutkan dengan proses 
pengepakan dan pembungkusan yang baik maka akan dihasilkan produk kripik tempe yang baik dan berkualitas.

\section{KESIMPULAN DAN SARAN}

\section{Kesimpulan}

Berdasarkan hasil analisis dan pembahasan pada bab terdahulu, maka kesimpulan yang dapat diambil dari penelitian ini adalah sebagai berikut:

1. Hasil analisis menunjukkan bahwa faktor pembeli, faktor pemasok, faktor teknologi, faktor pemerintah, faktor pemasaran, faktor keuangan dan faktor produksi secara simultan berpengaruh signifikan terhadap keberhasilan industri kecil kripik tempe di daerah Sanan yaitu ditunjukkan dengan nilai $\mathrm{F}$ hitung sebesar 12,320 dengan signifikansi a = 0,000 yaitu a lebih kecil dari 0,05. Maka model regresi dapat dipakai untuk memprediksi variabel keberhasilan industri atau dengan kata lain faktor pembeli, pemasok, teknologi, pemerintah, pemasaran, keuangan dan produksi secara bersama-sama berpengaruh terhadap keberhasilan industri.

2. Nilai koefisien determinasi (Adjusted $R^{2}$ ) sebesar 0,590 yang berarti Hal ini berarti sekitar $59 \%$ keberhasilan industri dapat dijelaskan oleh faktor pembeli, pemasok, teknologi, pemerintah, pemasaran, keuangan dan produksi, sedangkan sisanya (100\% - 59\%) yaitu sebesar $41 \%$ dijelaskan oleh sebab-sebab lain yang tidak diamati penelitian ini.

3. Hasil analisis regresi secara parsial melalui t-test, menunjukkan bahwa dari 7 faktor yang dianalisis terdapat 4 faktor yang signifikan pada $a<5 \%$ yaitu : faktor pemasok dengan nilai signifikan $t=0,018$, faktor teknologi dengan nilai signifikan $\mathrm{t}=0,046$, faktor pemasaran dengan nilai signifikan $\mathrm{t}=0,007$ dan faktor produksi dengan nilai signifikan $t=0,001$. Keempat faktor tersebut secara parsial berpengaruh signifikan dan positif terhadap tingkat keberhasilan industri kecil kripik tempe di daerah Sanan sedangkan faktor pembeli, pemerintah dan keuangan secara parsial tidak berpengaruh signifikan.

4. faktor produksi yang meliputi skala ekonomis produksi, karyawan yang terampil, kapasitas/kemampuan berproduksi, ketepatan waktu dalam 
berproduksi, kemampuan teknis pengusaha merupakan faktor yang dominan, hal tersebut dapat dilihat dari nilai Betanya sebesar 0,574 yaitu nilainya lebih besar dari faktor yang lain sedangkan faktor lainnya menjadi faktor pendukung yang mempengaruhi keberhasilan industri kripik tempe di daerah Sanan.

\section{Saran}

1. Faktor produksi merupakan faktor dominan sehingga pada masa yang akan datang diharapkan pengusaha harus lebih banyak memperhatikan faktor produksi. Disamping itu pengrajin juga harus memperhatikan faktor-faktor lainnya seperti pemasok, teknologi, pemerintah dan pemasaran.

2. Untuk meningkatkan perkembangan industri kripik tempe di daeran Sanan Kota Malang, sebaiknya pemerintah dalam hal ini Dinas Perindustrian dan Perdagangan melakukan pembinaan secara intensif kepada para pengrajin, terutama dalam hal manajemen, keuangan, produksi dan pemasaran.

3. Untuk meningkatkan kinerja perusahaan yang baik, maka industri harus mampu melakukan efisiensi dengan terus meningkatkan mutu produk dan produktifitasnya, serta meningkatkan kinerja keuangan yang dimiliki.

4. Peneliti yang akan datang dapat meneruskan dan menyempurnakan penelitian ini pada obyek yang lebih memadai dan lebih memperdalam indikator-indikator penelitian atau memasukkan faktor-faktor lain yang belum dibahas dalam penelitian ini .

\section{DAFTAR PUSTAKA}

Anonymous. 2000. Kecamatan Blimbing dalam Angka tahun 2000; BPS Kotamadya Malang . 2001. Kota Malang Dalam Angka Tahun 2001. BPS Kotamadya Malang 2001. Kampung Sanan Diarahkan Jadi Obyek Pariwisata. Harian Umum Kompas, Jumat 19 Oktober 2001.

2002. Jumlah Perajin Semakin Banyak. Peningkatannya Lamban. Harian Umum Kompas, Kamis 25 April 2002. Malang. 2002. Potret Industri Kecil. Majalah Techno. Universitas Brawijaya 2002. Masalah Industri Kecil. Majalah Techno. Universitas Brawijaya Malang. 
2003. UKM Orientasi Eksport. Harian Umum Jawa Pos, Selasa 10 Juni 2003.

Arikunto, Suharsimi. 1998. Prosedur Penelitian : Suatu pendekatan praktek; Edisi Revisi IV; Cetakan Kesebelas; Jakarta: Rineka Cipta.

Bernice Kotey and G.G, Meredith. 1997. Relationship among owner / manager personal value. business strategis and enterprise performance. Journal of Small Business Management, pp 37-61.

Bracker S, B.W. Keats, J.N. Pearson. 1988. Planning and Financial Performance Among Small Firms. Strategic Management Journal. November, pp 591-603.

David J. Hunger \& Thomas L. Wheelen. 2001. Manajemen Strategis. Yogyakarta: Penerbit ANDI.

Fandy Tjiptono. 2000. Strategi Pemasaran, Edisi Kedua, Cetakan Keempat. Yogyakarta: Penerbit ANDI.

Fogel Georgine. 2001. Global Prespektive: An Analysis of Entrepreneurial Environment and Enterprise Development in Hungary. Journal of Small Business Management, January, page 103-109.

Glueck, W.F., dan L.R. Jauch. 1999. Manajemen Strategis dan Kebijakan Perusahaan, Diterjemahkan oleh Drs. Murad, M.Sc dan AR. Henry Sitanggang, SH., Edisi Ketiga. Jakarta: Penerbit Erlangga.

Hair, Anderson, Tathan, Black. 1998. Multivariate Data Analysis. Singapore : Prentice Hall International-Prentice Hall Inc.

Hise.T Richard, Myron Gable, J. Patrick Kelly, James B. McDonald. 1983. Factor Affecting the Performance of Individual Chain Store Units : An Empirical Analysis. Journal of Retailing, Vol 59, No 2 (Summer 1983), pp. 22-39.

Husein Umar. 1999. Metodologi Penelitian Aplikasi Dalam Pemasaran. Jakarta: Penerbit PT. Gramedia Pustaka Utama.

I Wayan Wisardjo (2000). Analisis lingkungan industri kerajinan ukiran kayu di kabupaten gianyar provinsi Bali. Tesis. Program Pascasarjana Universitas Brawijaya Malang.

Kotler, Philip. 1993. Manajemen Pemasaran : Analisis, perencanaan, implementasi dan pengendalian, Vol satu. Lembaga Penerbit Fakultas Ekonomi Universitas Indonesia.

Malhotra Naresh K. 1999. Marketing Research; An Applied Orientation. New Jersey: Prentice Hall. Inc

Marzuki. 1995. Metodologi Riset. Cetakan Keenam. Yogyakarta: Penerbit BPFE.

McMahon G.P Richard. 2001. Business Growth and Performance and the Financial Reporting Practice of Australian Manufacturing SMEs. Journal of Small Business Management, April, Page 152-164.

Moeljadi P.1999. Pengaruh Beberapa Faktor Internal Perusahaan dan Asistensi Pemerintah Terhadap Kinerja Industri Kecil Di Jawa Timur. Jurnal Penelitian. Lembaga Penelitian Masyarakat Universitas Brawijaya. 
Nasir M. 1998. Metode Penelitian, Cetakan Ketiga. Penerbit Ghalia Indonesia.

Pierce II, John A dan Richard B. Robinson Jr..1997. Manajemen Strategik Formulasi, Implementasi, dan Pengendalian, Diterjemahkan oleh Ir. Agus Maulana MSM. Jakarta: Penerbit Binarupa Aksara.

Roger Brooksbank. 1999. The theory and prctice of marketing planning in the smaller business. Journal of Marketing Intelligence \& Planning. MCB University Press. Vol 2 / 1999, page 78-90.

Sawitri D (1999) Faktor-faktor keunggulan strategis yang berpengaruh terhadap kinerja industri genting di kabupaten Trenggalek. Tesis. Program Pascasarjana Universitas Brawijaya Malang.

Singarimbun, Masri dan Sofian Effendi. 2000. Metode Penelitian Survey. Jakarta: Penerbit LP3ES.

Singgih Santoso. 1999. Buku Latihan SPSS Statistik Parametrik. Jakarta: Penerbit PT Elex Media Komputindo.

Singgih Santoso dan Fandy Tjiptono. 2001. Riset Pemasaran Konsep dan Aplikasi dengan SPSS. Jakarta: Penerbit PT Elex Media Komputindo.

Solimun. 2002. Mulivariate Analysis Equation Modelling (SEM) Lisrel dan Amos., Cetakan I. Fakultas MIPA Universitas Brawijaya Malang.

Sulistyowati (1997) Analisis faktor lingkungan industri yang berpengaruh terhadap keberhasilan industri kerajinan tenun siak di Kotamadya Pekanbaru. Tesis. Program Pascasarjana Universitas Brawijaya Malang.

Tin Agustina Karnawati (1999) Analisis variabel-variabel yang mempengaruhi kinerja usaha industri kecil pengolahan makanan di Kotamadya Malang. Tesis. Program Pascasarjana Universitas Brawijaya Malang.

Tulus T.H Tambunan. 2002. Usaha Kecil dan Menengah di Indonesia-Beberapa Isu Penting, Edisi Pertama. Penerbit Salemba Empat. 